\title{
Islet adaptive changes to fructose-induced insulin resistance: $\beta$-cell mass, glucokinase, glucose metabolism, and insulin secretion
}

\author{
B Maiztegui, M I Borelli, M A Raschia, H Del Zotto and J J Gagliardino \\ CENEXA, Centro de Endocrinología Experimental y Aplicada (UNLP-CCT LA PLATA-CONICET, Centro Colaborador OPS/OMS en Diabetes), Facultad de \\ Ciencias Médicas, 60 y 120, 1900 La Plata, Argentina \\ (Correspondence should be addressed to J J Gagliardino; Email: cenexa@speedy.com.ar)
}

\begin{abstract}
$\beta$-Cell mass, hexokinase/glucokinase (HK/GK) activity, glucose metabolism and insulin secretion were studied in the islets of rats with fructose-induced insulin resistance (IR). Normal male Wistar rats were fed a standard commercial diet and water without (control, C) or with $10 \%$ fructose-rich diet (FRD) for 3 weeks. Blood glucose (strips), triglyceride (commercial kit), and insulin (RIA) levels were measured at the time of death. Glucose-induced insulin release, glucose metabolism $\left({ }^{14} \mathrm{CO}_{2}\right.$ and ${ }^{3} \mathrm{H}_{2} \mathrm{O}$ production from $\mathrm{D}-\left[\mathrm{U}-{ }^{14} \mathrm{C}\right]-$ and $\mathrm{D}-\left[5_{-}{ }^{3} \mathrm{H}\right]$-glucose) and HK/GK activity (G-6-P production), transcription (RTPCR), protein expression (Western blot), and cellular compartmentalization were measured in isolated islets (collagenase digestion). FRD rats presented normoglycemia but impaired glucose tolerance, hypertriglyceridemia, hyperinsulinemia, and increased HOMA-IR index. In these
\end{abstract}

rats, $\beta$-cell mass decreased significantly by $33 \%$, with a $44 \%$ increase in the percentage of apoptotic cells. Glucoseinduced insulin release and islet glucose metabolism were higher in FRD rats. While GK activity (total and cytosolic fraction) and protein expression were significantly higher in FRD islets, HK showed no change in any of these parameters. Our results demonstrate that the changes induced by dietary-induced IR upon $\beta$-cell function and mass are strongly conditional on the nutrient model used. In our model (intact animals with impaired glucose tolerance), GK activity increases through mechanisms previously shown only in vitro or under highly hyperglycemic conditions. Such an increase plays a pivotal role in the adaptive increased release of insulin in response to IR, even in the presence of marked $\beta$-cell mass reduction.

Journal of Endocrinology (2009) 200, 139-149

\section{Introduction}

Glucose homeostasis depends on the balance between insulin levels and the response of peripheral tissues to insulin action; it can remain normal even when insulin action decreases due to a compensatory increase in $\beta$-cell insulin release (Kahn et al. 1993). This increase depends on the combination of a higher secretory capacity of individual $\beta$-cells and an increase in the number of such cells. The former is related to an increased sensitivity of $\beta$-cells to glucose stimulus (Marynissen et al. 1990, Chen et al. 1993), whereas the mechanism of the latter has not been completely elucidated. Failure of $\beta$-cell adaptation to the increased demand of insulin will result in impaired glucose homeostasis and, in time, development of type 2 diabetes (Weyer et al. 1999). The homeostatic failure involves two progressive defective processes, namely, insufficient release of insulin (Porte 1991) and decrease in $\beta$-cell mass (Ogilvie 1933, Klöppel et al. 1985, Butler et al. 2003).

Evidence in the literature has shown that glucokinase (GK) activity plays a pivotal role upon islet glucose metabolism and insulin secretion. As opposed to other hexokinases (HK), GK kinetics shows a cooperative glucose dependence
(Hill coefficient 1.7), low affinity for glucose, and the lack of end-product inhibition by glucose-6-phosphate (Magnuson \& Matschinsky 2004). Due to these properties, GK responds quickly to changes in glucose concentrations under physiological conditions, thus becoming suitable to act as a glucose sensor (Matschinsky \& Davis 1998).

Chen et al. (1994a) have shown that islets isolated from rats with hyperinsulinemia induced by continuous 48 -h perfusion with 50 or $20 \%$ glucose, release more insulin in response to glucose and have an incremented catalytic GK activity, with or without a concomitant increase in GK protein content. GK activity, glucose usage and glucose-stimulated insulin release have also been causally and linearly related in rat islets cultured for up to 7 days with different glucose concentrations (Liang et al. 1992). This evidence, however, was obtained in the presence of marked hyperglycemia or a high glucose concentration in the medium.

On the other hand, islets of rats with spontaneous insulin resistance (IR), normal fasting blood glucose and oral glucose tolerance test presented hyperinsulinemia and exhibited a higher rate of glucose-stimulated insulin secretion in vitro together with a significant increase in GK activity, without 
changes in GK protein expression (Chen et al. 1994b). These results suggest that factors other than glucose also modulate the enzyme's activity. Thus, the mechanism by which IR triggers selective changes in GK activity and/or protein content to maintain glucose homeostasis within normal range also remains unclear.

It has been shown that GK activity is dependent of multiple modulators, such as its protein mass, its glucose-induced compartmentalization within $\beta$-cells (Tiedge et al. 1999, Stubbs et al. 2000, Rizzo et al. 2002) and, possibly, its interaction with the bifunctional regulatory enzyme 6-phosphofructo-2kinase/fructose-2,6-bisphosphatase (PFK-2/FBPase-2; Massa et al. 2004). These operating mechanisms have been proved in islet cells and cell lines, but there is no evidence for their occurrence in intact animal models with IR, normoglycemia and impaired glucose tolerance (IGT).

Concerning the mechanism for the adaptation of $\beta$-cells to an increased demand of insulin, Terauchi et al. (2007) have postulated that GK might be a common link between IR and the regulation of $\beta$-cell mass and function. To prove this hypothesis, these authors induced an IR state by administration of a high-fat diet (HFD) to either normal wild or $\mathrm{GK}^{+/-}$mice. Although their results are highly attractive, it is not clear whether they are merely concerned with the islets response to IR, or if they also depend on the metabolic changes induced by the HFD administration.

In an attempt to better understand the broad mechanisms involved in $\beta$-cell adaptation to an increased demand of insulin, we studied $\beta$-cell mass, insulin secretion, glucose metabolism, and the activity, transcription, protein expression, and intracellular translocation (cellular cytosolic and particulate fractions) of $\mathrm{HK}$ and GK in islets isolated from rats fed with a fructose-rich diet (FRD), a dietary model that induces IR (Thorburn et al. 1989, Bezerra et al. 2000, Shulman 2000, Catena et al. 2003, Delbosc et al. 2005, Rebolledo et al. 2008).

\section{Materials and Methods}

\section{Chemicals and drugs}

Collagenase was obtained from Serva Feinbiochemica (Heidelberg, Germany), BSA (BSA, fraction V), and other reagents were from Sigma Chemical Co., Fructose was obtained from Corn Products International Inc., (Westchester, IL, USA).

\section{Experimental groups}

Normal male Wistar rats (180-200 g) were divided into two groups; the treated group had free access to a standard commercial diet plus $10 \%$ fructose $(\mathrm{w} / \mathrm{v})$ in the drinking water (FRD), and the other received the same solid diet and tap water (control, C) for 3 weeks. Water and food intake were measured daily, while individual body weight was recorded once a week. Animal experiments and handling were performed according to the 'Ethical principles and guidelines for experimental animals' (3rd Edition 2005) from the Swiss Academy of Medical Sciences (mail@samw.ch).

\section{Blood measurements}

At the end of the 3-week period of FRD feeding, blood samples were collected $(0900 \mathrm{~h})$ from the orbital plexus under light halothane anesthesia to measure plasma glucose, triglyceride and insulin levels. Glucose was measured with test strips (One touch Ultra, Lifescan, Milpitas, CA, USA) and triglyceride levels were assayed with commercial kits implemented in an automated clinical analyzer. Plasma insulin was measured by RIA (Herbert et al. 1965) using an antibody against rat insulin, rat insulin standard (Linco Research Inc., St Charles, MO, USA) and highly purified porcine insulin labeled with ${ }^{125}$ I (Linde et al. 1980). IR was assessed with the HOMA-IR index, calculated as insulin $(\mu \mathrm{U} / 1) \times$ glucose (mmol/l)/22.5 (Matthews et al. 1985, Nandhini et al. 2005).

\section{I.p. glucose tolerance}

The day before the animals were killed, glucose tolerance was measured in 12-h fasted rats after i.p. glucose injection $(1 \mathrm{~g} / \mathrm{kg}$ in saline). Blood samples were obtained from the orbital plexus at 0 , $15,30,60$, and $120 \mathrm{~min}$ following the i.p. glucose load, under pentobarbital anesthesia $(48 \mathrm{mg} / \mathrm{kg}$ ). Results were expressed as the area under the glucose curve (AUC) in $\mathrm{mmol} / \mathrm{l}$ per $\mathrm{min}$.

\section{Pancreas removal and islet isolation}

After blood collection, the animals from both groups were killed (0900 h) by cervical dislocation. The pancreas from each animal was removed to isolate islets by collagenase digestion (Lacy \& Kostianovsky 1967). To study GK and HK activity, isolated islets were homogenized in $50 \mathrm{mM}$ HEPES-NaOH buffer $(\mathrm{pH} 7 \cdot 5)$ with $6 \mathrm{mM} \mathrm{MgCl}_{2}, 60 \mathrm{mM} \mathrm{KCl}, 10 \mathrm{mM} \mathrm{KPO}{ }_{4} \mathrm{H}_{2}, 1 \mathrm{mM}$ EDTA, $1 \mathrm{mM}$ l-cysteine, and $0 \cdot 02 \%$ BSA; to measure protein expression the islets were homogenized in $80 \mathrm{mM}$ Tris (pH 6.8), $5 \mathrm{mM}$ EDTA, 5\% SDS, 5\% dithiothreitol, 10\% glycerol and protease inhibitors ( $1 \mathrm{mM}$ phenyl-methylsulfonyl-fluoride, $4 \mathrm{mg}$ aprotinin, and $0.1 \mathrm{mM}$ benzamidine). Part of both homogenates was centrifuged for $5 \mathrm{~min}$ at $5000 \mathrm{~g}$ to remove intact cells and cell debris, and the supernatant was then centrifuged for $90 \mathrm{~min}$ at $4{ }^{\circ} \mathrm{C}$ at $100000 \mathrm{~g}$ to separate the particulate (pellet) and cytosolic (supernatant) fractions. The pellet was then suspended in $150 \mu$ of the specific assay buffer. Protein concentration from the different fractions (homogenate, particulate, and cytosolic) was quantified using the Bio-Rad protein assay (Bradford 1976).

\section{Insulin secretion in vitro}

Groups of five islets were incubated for $60 \mathrm{~min}$ at $37^{\circ} \mathrm{C}$ in

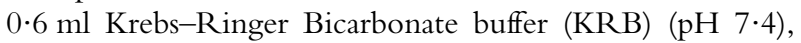
previously gassed with $\mathrm{CO}_{2} / \mathrm{O}_{2}(5 / 95 \%)$, containing $1 \%$ 
(w/v) BSA and different glucose concentrations $(2,4,8,12$, 16, and $20 \mathrm{mM}$; Gagliardino et al. 1974). At the end of the incubation period, aliquots from the medium were taken to measure insulin by RIA (Herbert et al. 1965).

\section{Glucose oxidation and utilization}

Groups of 20 islets were incubated in a small tube containing $40 \mu \mathrm{l}$ KRB buffer supplemented with $10 \mathrm{mM}$ HEPES $(\mathrm{pH} \quad 7 \cdot 4), \quad \mathrm{D}-\left[\mathrm{U}_{-}{ }^{14} \mathrm{C}\right]$-glucose, and $\mathrm{D}-\left[5-{ }^{3} \mathrm{H}\right]$-glucose $(10 \mathrm{MCi} / \mathrm{ml},(300 \mathrm{MCi} / \mathrm{mmol}))$ in the presence of 3.3 or $16.7 \mathrm{mM}$ glucose. This tube together with an empty one was placed inside an airtight-sealed $20 \mathrm{ml}$ glass vial containing $500 \mu \mathrm{l}$ distilled water in the bottom. After $2-\mathrm{h}$ incubation at $37^{\circ} \mathrm{C}$, the reaction was stopped by injecting $20 \mu \mathrm{l}$ of $400 \mathrm{mM}$ citric acid, $10 \mathrm{mM}$ rotenone, $10 \mathrm{mM}$ antimycin, and $3 \mathrm{mg} \mathrm{KCN} \mathrm{(pH} \mathrm{4.9)} \mathrm{to} \mathrm{the} \mathrm{incubation} \mathrm{media;} \mathrm{at} \mathrm{the}$ same time $250 \mu$ l hyamine were added to the empty tube. After a second incubation for $60 \mathrm{~min}$ at $37{ }^{\circ} \mathrm{C}$, the ${ }^{14} \mathrm{CO}_{2}$ fixed to hyamine was measured in vials containing $5 \mathrm{ml}$ scintillation liquid (Ultima Gold XR, Packard Waltham, MA, USA). The islets were further incubated overnight at room temperature and glucose utilization was measured as ${ }^{3} \mathrm{H}_{2} \mathrm{O}$ production captured by water in $5 \mathrm{ml}$ scintillation liquid (Malaisse \& Sener 1988).

\section{HK/GK activity}

Groups of 20 isolated islets ( 1 islet/ $\mu$ l) were homogenized and processed as described above; $20 \mu \mathrm{l}$ of the whole homogenate were then combined with another $20 \mu$ of the reaction mixture (HEPES- $\mathrm{NaOH}, 10 \mathrm{mM}$ ATP, $20 \mathrm{MCi} / \mathrm{ml}$ $(300 \mathrm{MCi} / \mathrm{mmol})$ of $\mathrm{D}^{-}\left[\mathrm{U}_{-}{ }^{14} \mathrm{C}\right]$-glucose, and $1-100 \mathrm{mM}$ unlabeled D-glucose) and incubated for $60 \mathrm{~min}$ at $37^{\circ} \mathrm{C}$. The pellet or the cytosolic fraction of islet homogenates was incubated under the same conditions but with 1 or $100 \mathrm{mM}$ unlabeled D-glucose. The reaction was stopped by addition of $1 \mathrm{ml}$ iced water, and each sample was then passed through a column of AG $1-\mathrm{X} 8$ to separate $\mathrm{D}-\left[\mathrm{U}-{ }^{14} \mathrm{C}\right]$-glucose-6phosphate from $\mathrm{D}-\left[\mathrm{U}_{-}{ }^{14} \mathrm{C}\right]$-glucose by ion exchange chromatography (Giroix et al. 1984). The hexose phosphate was eluted from the column with $1 \mathrm{M}$ ammonium formate/ $0 \cdot 1 \mathrm{M}$ formic acid. The eluate was then mixed with $10 \mathrm{ml}$ scintillation fluid, measuring its radioactivity in a liquid scintillation spectrophotometer. The same mixture but without islet tissue was used as a blank. Under these conditions, the G-6-P production obtained in the presence of 1 and $100 \mathrm{mM}$ unlabeled glucose corresponded to HK and GK activity respectively. HK and GK kinetics studies were conducted with the same procedure, but using a wide range of glucose concentrations $(1-100 \mathrm{mM})$. GK kinetic parameters were fitted to the Hill equation $V=V_{\max }(\mathrm{Glc})^{h} /\left(K_{0.5}^{h}+(\mathrm{Glc})^{h}\right)$, where $V$ is the reaction rate normalized to the enzyme concentration, $(\mathrm{Glc})$ is the glucose concentration, $K_{0.5}$ is the glucose concentration at half-maximal activity, and $h$ is the Hill coefficient, which indicates the level of glucose cooperativity. Since HK exhibits Michaelis-Menten kinetics, to measure its $K_{\mathrm{m}}$ and $V_{\max }$ we used the Eadie-Hofstee plot $\left(v_{\mathrm{i}}=K_{\mathrm{m}} \times v_{\mathrm{i}} / S+V_{\max }\right)$, where $v_{\mathrm{i}}$ is the initial velocity and $S$ is the substrate concentration.

\section{Isolation of total RNA and expression of $H K$ and $G K m R N A$}

Total RNA was separately obtained from $\mathrm{C}$ and FRD rat islets using TRIzol Reagent (Gibco-BRL; Chomczynski \& Sacchi 1987). The integrity of isolated RNA was checked by $1 \%$ agarose-formaldehyde gel electrophoresis (Sambrook et al. 1989). Possible contamination with protein or phenol was controlled by measuring the $260 / 280 \mathrm{~nm}$ absorbance ratio, while DNA contamination was avoided using DNAase I 1U/ $\mathrm{ml}$ (Gibco-BRL). RT-PCR was performed using the Super Script III reverse transcriptase $(200 \mathrm{U} / \mathrm{ml}$; Gibco-BRL) and total RNA (50 ng) from C and FRD islets as template. We used specific primers based on the rat cDNA sequence to measure GK and HK mRNA (GenBank accession numbers: GK, M25807, sense primer: 5'-AGGCCACCAAGAAGGAAAAG-3', antisense primer: 5'-TTGTCTTCACGCTCCACTGC-3' (Schuit et al. 1999); HK, J04526, sense primer: 5'-GGCTCAGAGGAGACCCTTCG-3', antisense primer: $5^{\prime}$-CCAGGTCGAACTTGAATCAT-3' (Jonas et al. 1999).

$\boldsymbol{\alpha}$-Tubulin (J00797) was used as internal control (sense primer: $5^{\prime}$-CTCGCATCCACTTCCCTC- $3^{\prime}$, antisense primer: 5'-ATGCCCTCACCCACGTAC-3'; Jonas et al. 1999). Possible contamination with genomic DNA was checked by performing RT-PCR with or without the SuperScript III RT.

The cycling profile for GK was the following: $2.5 \mathrm{~min}$ at $95^{\circ} \mathrm{C}$ followed by $1 \mathrm{~min}$ at $94{ }^{\circ} \mathrm{C}, 1.5 \mathrm{~min}$ at $65^{\circ} \mathrm{C}$, and $1.5 \mathrm{~min}$ at $72{ }^{\circ} \mathrm{C}$ for 10 cycles; and $0.5 \mathrm{~min}$ at $94^{\circ} \mathrm{C}, 1 \mathrm{~min}$ at $60{ }^{\circ} \mathrm{C}$, and $1.5 \mathrm{~min}$ at $72{ }^{\circ} \mathrm{C}$ for 21 cycles, resulting in a total number of 31 cycles (Schuit et al. 1999).

PCR conditions for HK were 10 min denaturing step at $94{ }^{\circ} \mathrm{C}$, followed by $1 \mathrm{~min}$ at $94^{\circ} \mathrm{C}, 1 \mathrm{~min}$ at $55^{\circ} \mathrm{C}$, and $1 \mathrm{~min}$ at $72^{\circ} \mathrm{C}$ for 33 cycles, and a final extension step of $10 \mathrm{~min}$ at $72{ }^{\circ} \mathrm{C}$. Under these conditions, the PCR was in the linear range of amplification. PCR products were separated by electrophoresis on a $2 \%(\mathrm{w} / \mathrm{v})$ agarose gel and stained with ethidium bromide. Band density was measured using a Kodak DC290 digital camera and the Kodak 1D Image Analysis Software.

\section{Western blot}

Proteins from islet homogenate, cytosol, and particulate fractions $(10,10$, and $2 \mathrm{ng}$ respectively) obtained from both experimental groups were fractioned on reducing $7 \cdot 5 \%$ SDS-PAGE and electroblotted to polyvinylidene difluoride membranes. Non-specific binding sites were blocked with a non-fat milk solution at $4{ }^{\circ} \mathrm{C}$. Measurement of $\mathrm{HK}$ and GK protein levels was performed by immunoblots using the specific primary antibodies against HK (mouse anti-type 
1 HK monoclonal antibody, Chemicon International Inc., Temecula, CA, USA) or GK (sheep anti-GST-GK fusion protein antibody, kindly provided by Dr Mark Magnusson, Vanderbilt University, Vanderbilt, TN, USA) at a 1:2000 final dilution. After rinsing with tris buffered saline, the membranes were further incubated with the streptavidinperoxidase conjugate anti-mouse or anti-sheep IgG and rinsed in TBS. Diaminobenzidine (Sigma Co.,) and electrochemiluminescence (Amersham Biosciences) were added for color or chemiluminescence development respectively. Band density was measured as described above.

\section{Immunohistochemical studies}

The whole pancreas was carefully dissected and removed from each experimental group, and its wet weight was recorded. The pancreas was then fixed in $10 \%$ formaldehyde and embedded in paraffin. Serial sections of fixed pancreas $(5 \mu \mathrm{m})$ were cut from three different depth of the blocks with a rotatory microtome and mounted on silanized slides (3-amino-propyltriethoxy-silane; Sigma Co., Hsu et al. 1981). Sections were deparaffinized, incubated for $30 \mathrm{~min}$ in $3 \%$ hydrogen peroxide in methanol to block the endogenous peroxidase activity, and rehydrated in a descending ethanol series, followed by incubation in $2.5 \%$ porcine serum to reduce non-specific binding. The slides were then incubated for $24 \mathrm{~h}$ at $4{ }^{\circ} \mathrm{C}$ in a humidified chamber with our own anti-guinea pig insulin antibody $(1: 20000)$. The final staining was performed by incubating the slides for $30 \mathrm{~min}$ with appropriately diluted streptavidin-biotin complex (1:40 and 1:20 respectively; Sigma); thereafter, the sections were stained with hematoxylin.

\section{Morphometric analysis}

Morphometric analysis was performed by videomicroscopy using a Jenamed 2 Carl Zeiss light microscope and an RGB CCD Sony camera, together with the OPTIMAS software (Bioscan Incorporated, Edmons, WA, USA). We measured the following parameters: total pancreatic area (excluding connective tissue), exocrine, and endocrine pancreatic area; $\beta$-cell area; the number of $\beta$-cells, the number of islets per unit area, and single islet volume. We also estimated volume density and individual size of $\beta$-cells. To estimate islet $\beta$-cell mass, we multiplied the respective volume densities by the weight of the total pancreas (Bonner-Weir \& Smith 1994).

\section{Apoptotic $\beta$-cells}

We used the propidium iodide technique to identify apoptotic bodies (Scaglia et al. 1997). Pancreas sections were deparaffinized, rehydrated, and then incubated for $30 \mathrm{~min}$ in a darkness humidified chamber with a propidium iodide ( $4 \mu \mathrm{g} / \mathrm{ml}$; Sigma) and ribonuclease A $(100 \mu \mathrm{g} / \mathrm{ml}$; Sigma $)$ solution. Then, the sections pre-treated with guinea pig non-immune sera diluted in Tris-buffered saline $(\mathrm{pH} \mathrm{7 \cdot 4)}$ were incubated for $1 \mathrm{~h}$ with the insulin antibody. To measure the fluorescence labeling of the primary antibody, the slides were incubated at room temperature for $45 \mathrm{~min}$ in the darkness chamber with the IgG-specific, fluorescein-conjugated, affinity-purified goat antibody (against heavy and light IgG chains; Jackson Immuno Research Laboratories, Baltimore, MD, USA). Following a wash with PBS, sections were mounted in Tris-glycerol ( $\mathrm{pH} \mathrm{8.4)} \mathrm{for} \mathrm{analysis} \mathrm{with} \mathrm{a}$ fluorescence microscope. Using this double labelling procedure, we identified $\beta$-cell apoptosis with an immunofluorescent Zeiss Axiolab epifluorescence microscope equipped with an HBO50 mercury lamp, together with two different filters. For the quantitative evaluation of apoptosis, positively immunofluorescence-labeled $\beta$-cells were counted under a $40 \times$ objective lens in sections obtained from different levels of the blocks. The number of apoptotic $\beta$-cells was expressed as the percentage of the total number of $\beta$-cells counted.

\section{Calculations and statistical analysis}

Results of HK and GK protein expression and activity from the cytosol and the particulate fractions were calculated as a percentage of each one with respect to total band intensity or a total activity (sum of the measurements of both fractions) respectively.

The experimental data were analyzed using the Student's $t$-test. Differences were considered significant when $P<0 \cdot 05$.

\section{Results}

\section{Body weight and water intake}

After the 3-week treatment, comparable body weights were recorded in both groups of rats (C and FRD, 261.50 $\pm 2 \cdot 51$ and $262 \cdot 60 \pm 2 \cdot 42 \mathrm{~g}$; NS). FRD rats drank a significantly larger volume of water than C (C and FRD, 25.00 \pm 2.50 and $39 \cdot 80 \pm 1 \cdot 80 \mathrm{ml} /$ day; $P<0 \cdot 001)$. Conversely, the amount of solid food ingested was significantly greater in $\mathrm{C}$ when compared with FRD rats $(19 \cdot 26 \pm 1.52$ and $13 \cdot 37 \pm$ $1 \cdot 30 \mathrm{~g} /$ animal/day respectively; $P<0 \cdot 001)$. This fact resulted in a different percent daily intake of nutrients in $\mathrm{C}$ compared with FRD (carbohydrates: proteins: lipids, 45:43:12 and 60:31:9 respectively), and a comparable caloric intake (C and FRD, $55 \cdot 65 \pm 4 \cdot 54$ and $50 \cdot 79 \pm 3 \cdot 43 \mathrm{Kcal} /$ day; NS).

\section{Blood glucose and serum insulin levels}

There were no significant differences in blood glucose levels between groups (C and FRD, 130.80 $\pm 4 \cdot 40$ and 131.60 $3.20 \mathrm{mg} / \mathrm{dl}$; NS). However, FRD rats had significantly higher serum insulin (C and FRD, 0.77 \pm 0.05 and $1.15 \pm$ $0.07 \mathrm{ng} / \mathrm{ml} ; \quad P<0.001)$ and plasma triglyceride (C and FRD, $98 \cdot 40 \pm 3.50$ and $158.90 \pm 5.50 \mathrm{mg} / \mathrm{dl} ; \quad P<0 \cdot 001)$ levels. As a consequence of the uneven changes of glucose 
and insulin levels in both experimental groups, the insulin: glucose molar ratio was $1.83 \times 10^{-8} \pm 1.49 \times 10^{-9}$ and $2 \cdot 67 \times 10^{-8} \pm 1.76 \times 10^{-9}$ for $\mathrm{C}$ and FRD rats respectively $(P<0 \cdot 001)$. All these parameters were measured in samples collected at $0900 \mathrm{~h}$ from randomly selected animals of both groups.

The IR index (HOMA-IR) was significantly higher in FRD animals (C compared with FRD, 5.45 \pm 0.46 and $9 \cdot 02 \pm 0 \cdot 68, P<0 \cdot 001)$, thus indicating the presence of an IR state in these rats.

\section{Glucose tolerance test}

Comparable blood glucose values were measured at time 0 in both groups of animals, but these values were significantly higher in FRD rats after the i.p. glucose load at 15, 30, and $60 \mathrm{~min}$. At $120 \mathrm{~min}$, glucose values returned to those initially measured (0 time), being similar in both groups of rats (Fig. 1). Consequently, the AUC was significantly higher in FRD than in $\mathrm{C}$ animals (C versus FRD, $1.56 \pm 0.64$ and $4 \cdot 29 \pm 0.49 \mathrm{mmol} / 1$ per $\mathrm{min} ; P<0 \cdot 01)$.

\section{Insulin secretion in vitro}

Islets isolated from both groups increased the release of insulin as a function of the glucose concentration in the incubation media (Fig. 2). FRD rat islets released significantly larger amounts of insulin than $\mathrm{C}$ rat islets in response to stimulatory glucose concentrations $(8,12,16$, and $20 \mathrm{mM})$, shifting the secretion curve to the left. However, no difference was recorded at lower glucose concentrations (2 and $4 \mathrm{mM}$ ).

\section{Glucose oxidation and utilization}

In both experimental groups, the production of ${ }^{14} \mathrm{CO}_{2}$ from D-[U- $\left.{ }^{14} \mathrm{C}\right]$-glucose and of ${ }^{3} \mathrm{H}_{2} \mathrm{O}$ from $\mathrm{D}-\left[5-{ }^{3} \mathrm{H}\right]$-glucose by isolated islets increased significantly when the glucose concentration in the incubation medium raised from 3.3 to $16.7 \mathrm{mM}$ (Fig. 3). In the presence of high glucose, ${ }^{14} \mathrm{CO}_{2}$

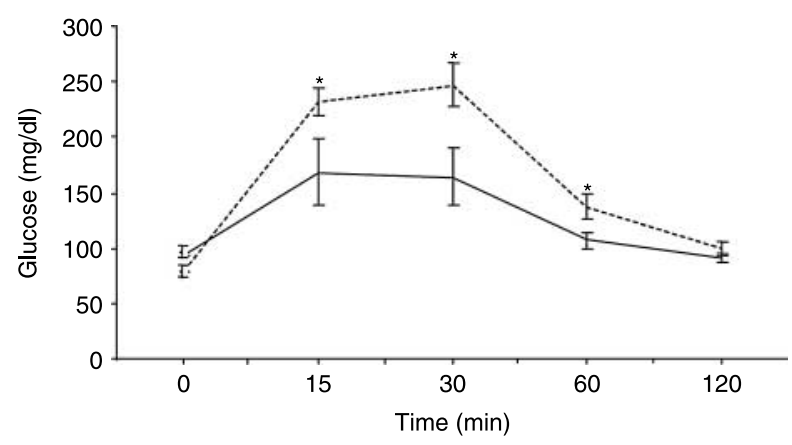

Figure 1 Blood glucose concentration at 0, 15, 30, 60, and $120 \mathrm{~min}$ following an i.p. glucose load ( $1 \mathrm{~g} / \mathrm{kg}$ body weight) in C (full line) and FRD (dotted line) rats. Values represent means \pm s.E.M. of three different experiments performed with six animals in each group. $* P<0 \cdot 05$.

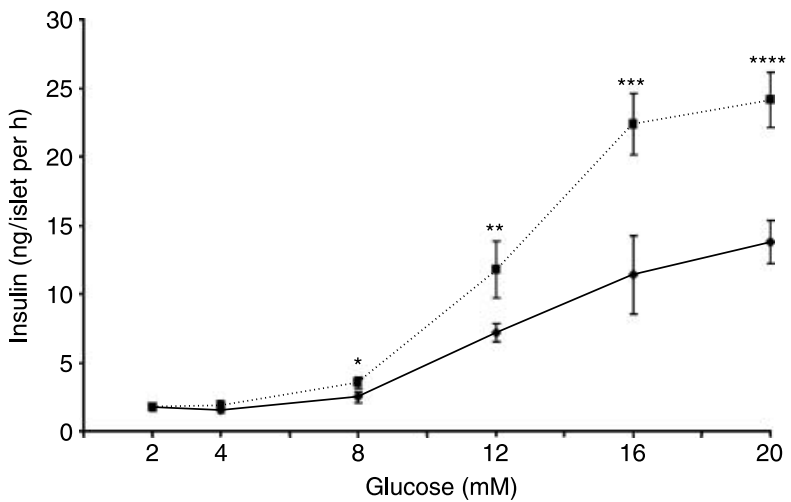

Figure 2 Glucose-induced insulin secretion in islets isolated from $\mathrm{C}$ (full line) and FRD (dotted line) rats. and $\mathbf{\square}$ represent means $\underline{ \pm}$ S.E.M. of five different experiments. ${ }^{*} P<0 \cdot 05,{ }^{* *} P<0 \cdot 02$, $* * * P<0 \cdot 005$, $* * * * P<0 \cdot 001$.

production was significantly higher (47\%) in FRD compared with $\mathrm{C}$ rat islets (Fig. 3A). On the other hand, ${ }^{3} \mathrm{H}_{2} \mathrm{O}$ production followed the same trend, being significantly higher in FRD islets (61\%) in the presence of either a lowor high-glucose concentration (Fig. 3B).

\section{$H K$ and $G K$ activity}

In our assay, the glucose phosphorylation rate measured in islet homogenates up to $1 \mathrm{mM}$ glucose represents an HK enzyme activity with a $K_{\mathrm{m}}$ of $110 \mu \mathrm{M}$ for glucose; whereas the rates
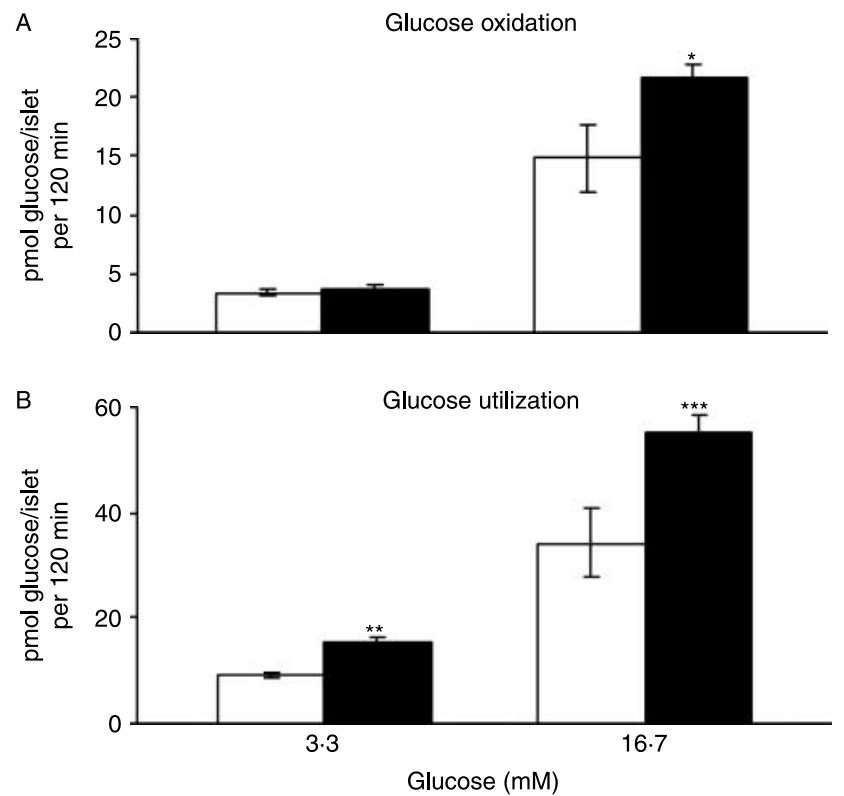

Figure 3 (A) Glucose oxidation and (B) utilization measured as ${ }^{14} \mathrm{CO}_{2}$ produced from D- $\left[\mathrm{U}-{ }^{14} \mathrm{C}\right]$-glucose and ${ }^{3} \mathrm{H}_{2} \mathrm{O}$ from D- $\left[5-{ }^{3} \mathrm{H}\right]-$ glucose respectively. Bars represent means \pm S.E.M. of four different experiments performed with islets isolated from each experimental group. ${ }^{*} P<0 \cdot 05, * * P<0 \cdot 005,{ }^{* * *} P<0 \cdot 025$. White bars, $\mathrm{C}$ rats; black bars, FRD rats. 
measured at increasing glucose concentrations (up to $100 \mathrm{mM}$ ) correspond to a GK enzyme, with a $K_{0}{ }_{5}$ close to $20 \mathrm{mM}$.

GK kinetics parameters exhibited the known positive cooperativity with glucose (Hill coefficient, C versus FRD, $1 \cdot 45 \pm 0 \cdot 37$ vs $1 \cdot 99 \pm 0 \cdot 11 ; \mathrm{NS}) ; K_{0} \cdot 5$ and maximal velocity $\left(V_{\max }\right)$ of $\mathrm{GK}$ measured in islet homogenates were significantly higher in FRD (C versus FRD, $K_{0}{ }^{\circ}, 20 \cdot 59 \pm$ 0.97 vs $37 \cdot 74 \pm 5 \cdot 41 \mathrm{mM} ; P<0.05$. $V_{\max }, 2 \cdot 99 \pm 0.04$ vs $5 \cdot 12 \pm 0.41 \mathrm{pmol}$ glucose $/ \mu \mathrm{g}$ prot $/ \mathrm{min} ; P<0 \cdot 001)$. Comparable $\mathrm{HK} K_{\mathrm{m}}$ and $V_{\max }$ values were measured in $\mathrm{C}$ and FRD rats $\left(K_{\mathrm{m}}, 110 \pm 30\right.$ vs $110 \pm 0 \cdot 3 \mu \mathrm{M}$, NS; $V_{\max }, 2 \cdot 41 \pm$ $0 \cdot 38$ vs $2 \cdot 14 \pm 0 \cdot 15 \mathrm{pmol}$ glucose $/ \mu \mathrm{g}$ prot $/ \mathrm{min}$; NS).

GK activity measured in islet homogenates of FRD (Fig. 4A) was significantly higher than that of $\mathrm{C}$ rats $(112.50 \%$ of control). GK activity measured in the cytosol and in the particulate fractions was referred to total activity (cytosol+ particulate fractions; Fig. 4B). In FRD animals, most of the GK activity was measured in the cytosolic fraction (highly active form), being significantly higher than in $\mathrm{C}$ islets (C versus FRD, 36.40 $\pm 5 \cdot 00$ vs $75 \cdot 50 \pm 11 \cdot 00 \%$ ). Conversely, GK activity measured in the particulate fraction (lowly active form) of FRD islets was low and significantly lower than that measured in $\mathrm{C}$ islets (C versus FRD, 63.60 \pm $12 \cdot 00$ vs $24 \cdot 50 \pm 2 \cdot 20 \%$ ).

No significant differences in $\mathrm{HK}$ activity were found between groups either in the homogenate (Fig. 4C) or in the cytosol and particulate fractions (Fig. 4D). Consequently, the GK/HK activity ratio was significantly higher $(130 \cdot 10 \%)$ in FRD than in $\mathrm{C}$ rats (C and FRD, $0 \cdot 73 \pm 0 \cdot 10$ and $1.68 \pm$ $0 \cdot 27 ; P<0 \cdot 002)$.

\section{$H K$ and $G K m R N A$}

There was no significant difference between groups in the intensity of the bands corresponding to GK and HK mRNA when compared with $\alpha$-tubulin (C and FRD; GK, $24 \cdot 15 \pm$ $2 \cdot 18$ and $24 \cdot 90 \pm 0 \cdot 93 \%$, NS; HK, $36 \cdot 60 \pm 2 \cdot 60$ and $40 \cdot 29 \pm$ $3 \cdot 10 \%, \mathrm{NS})$.

\section{Western blot}

Western blot performed in islet homogenates from $\mathrm{C}$ and FRD rats with specific GK and $\mathrm{HK}$ antibodies showed two single bands of about 50 and $109 \mathrm{kDa}$ respectively, compatible with the molecular weight of these two enzymes. The band intensity increased as a function of the protein concentration used, supporting the specificity of the immunoreactive measurement (data not shown). The intensity of the GK band was higher in FRD islet homogenates (C and FRD, $100 \cdot 00 \pm 6 \cdot 40$ and $154 \cdot 10 \pm 17 \cdot 90 \% ; P<0 \cdot 02$; Fig. 5$)$. The intensity of the GK band measured in the cytosolic fraction was higher in FRD (C and FRD, 36.00 $\pm 2 \cdot 30$ and $67 \cdot 60 \pm$ $2 \cdot 60 \%$ of the total intensity; $P<0 \cdot 001)$. As expected, the intensity of the GK band measured in the particulate fraction was higher in $\mathrm{C}$ animals ( $\mathrm{C}$ and FRD, 64.00 $\pm 2 \cdot 30$ and $32 \cdot 40 \pm 2 \cdot 50 \%$ of the total intensity; $P<0 \cdot 001$; Fig. 5).
A
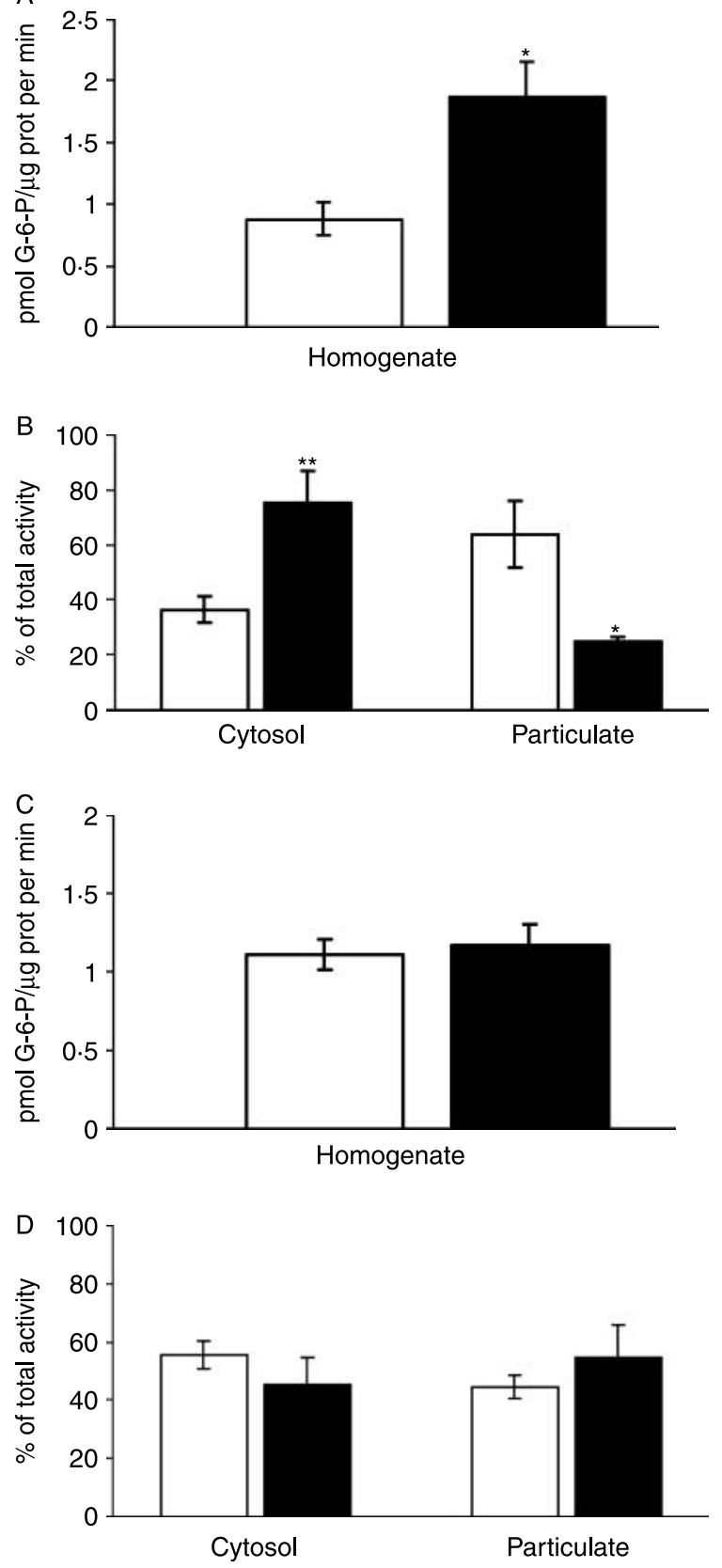

Figure 4 Glucose phosphorylation from different islet fractions (homogenate, cytosol, particulate) at 100 (GK, A and B) and 1 ( $H K, C$ and D) $\mathrm{mM}$ glucose. Bars represent means \pm s.E.M. of five different experiments performed with islets isolated from each experimental group. ${ }^{*} P<0 \cdot 005, * * P<0 \cdot 001$. White bars, $\mathrm{C}$ rats; black bars, FRD rats.

Interestingly, the magnitude of the relative changes in the GK protein was greater in both $\beta$-cell fractions than in whole homogenates. No significant difference was found in the intensity of the $\mathrm{HK}$ band (C and FRD, 100.0 \pm 11.7 and $99 \cdot 7 \pm 11 \cdot 8 \%$; NS; Fig. 5). 


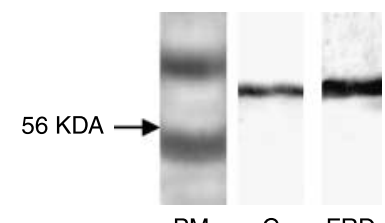

PM C FRD

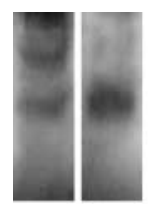

C FRD

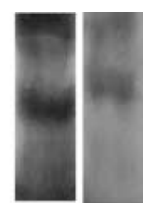

C FRD
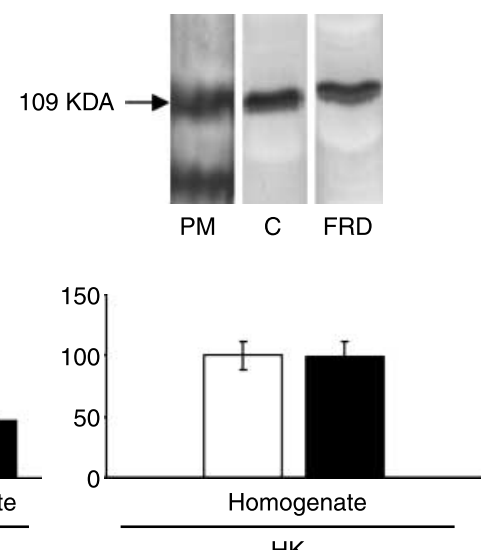

HK
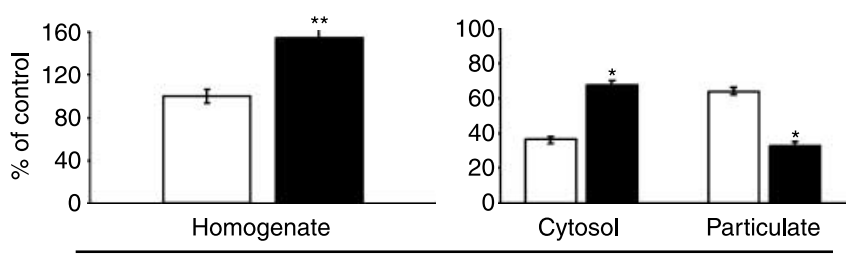

GK

Figure $5 \mathrm{GK}$ and HK expression (western blot) from C and FRD rats measured in islet homogenate, cytosolic, and particulate fractions. In all cases, molecular weight standards were used as internal control. Band intensities (relative values) are represented under the bands (white bars, C; black bars, FRD). Representative blot of four independent experiments. $\left({ }^{*} P<0 \cdot 02,{ }^{* *} P<0 \cdot 001\right)$.

\section{Morphometric analysis and $\beta$-cell apoptosis}

Pancreas weight did not differ between the experimental groups. FRD animals showed a significant decrease in the number of islets, total endocrine area, $\beta$-cell area, $\beta$-cell mass, single islet volume, islet area, and number of $\beta$-cells/islet (Table 1 and Fig. 6A and B). On the other hand, the percentage of apoptotic $\beta$-cells was significantly higher in FRD rats (C versus FRD, $0.62 \pm 0.03$ vs $1.11 \pm 0.04 \%$; $P<0 \cdot 05$; Fig. 6C-E).

\section{Discussion}

Our results show that the administration of a FRD to normal rats induces an IR state, as demonstrated by hyperinsulinemia with normoglycemia, high insulin: glucose molar ratio, and the HOMA-IR index. As reported previously, these rats also had significantly increased serum triglyceride levels (Thorburn et al. 1989).

FRD-induced IR is due to the combination of several factors, namely, a) reduction in the number of insulin

Table 1 Morphometric analysis of control and fructose-treated rats

\section{Control}

$608 \pm 88$

$2 \cdot 14 \pm 0 \cdot 06$

Pancreas weight $(\mathrm{mg})$ Number of islets $/ \mathrm{mm}^{2}$

Total endocrine area $(\%)$

$\beta$-cell area $(\%)$

$\beta$-cell mass (mg)

Single islet volume $\left(\mu^{3}\right)$

Islet area $\left(\mu^{2}\right)$

Number of $\beta$-cells/islet

\section{FRD}

$559 \pm 52$

$1 \cdot 08 \pm 0 \cdot 17^{*}$

$0 \cdot 69 \pm 0 \cdot 1^{*}$

$0 \cdot 65 \pm 0 \cdot 03^{*}$

$3 \cdot 89 \pm 0 \cdot 50^{*}$

$31 \times 10^{3} \pm 810^{*}$

$3068 \pm 78^{*}$

$29 \cdot 95 \pm 2 \cdot 31^{*}$
Values are means \pm S.E.M. from three different levels of the block corresponding to three animals of each group; ${ }^{*} P<0 \cdot 05$. C, control; FRD, fructose-rich diet. receptors in skeletal muscle and liver (Catena et al. 2003), b) alterations at post-insulin receptor level (Bezerra et al. 2000), c) increased rate of the free fatty acid-glucose cycle (Randle 1964, Shulman 2000), and d) increased gluco-oxidative stress (Delbosc et al. 2005, Rebolledo et al. 2008).

Rats fed with the FRD showed a significant decrease in the number of islets, total endocrine area, $\beta$-cell area, single islet volume, islet area and number of $\beta$-cells/islet, leading to a $33 \%$ decrease in $\beta$-cell mass, with a concomitant $44 \%$ increase in the percentage of apoptotic cells. We should thus assume that the increased percentage of apoptosis was not compensated by a similar increase in $\beta$-cell replication and neogenesis. Apoptosis in these animals could be stimulated by several and concurrent processes such as IR-related endoplasmic reticulum stress (Rutkowski \& Kaufman 2004) and glucolipotoxicity (Poitout \& Robertson 2002, Robertson et al. 2007). With reference to the latter process, it has been recently reported that adipose tissue of FRD rats releases larger amounts of fatty acids with a high saturated/unsaturated ratio both in vivo and in vitro (Rebolledo et al. 2008); the known enhancing effect of saturated fatty acids upon apoptosis would also favor the increment of $\beta$-cell apoptosis measured in these rats (Kharroubi et al. 2004). The apparent discrepancy between our results and those of Terauchi et al. (2007) are due to the different serum free fatty acids.

A comparable association of decreased $\beta$-cell mass and increased percentage of $\beta$-cell apoptosis has been previously described in obese people with impaired fasting glucose and type 2 diabetes (Butler et al. 2003). Thus, the data recorded in FRD rats support the concept that decreased $\beta$-cell mass is an early and progressive alteration involved in the pathogenesis of type 2 diabetes. These data also suggest that FRD is a useful model to study the mechanism/s responsible for the decrease of $\beta$-cell mass observed in human type 2 diabetes (Ogilvie 1933, Klöppel et al. 1985, Butler et al. 2003). 

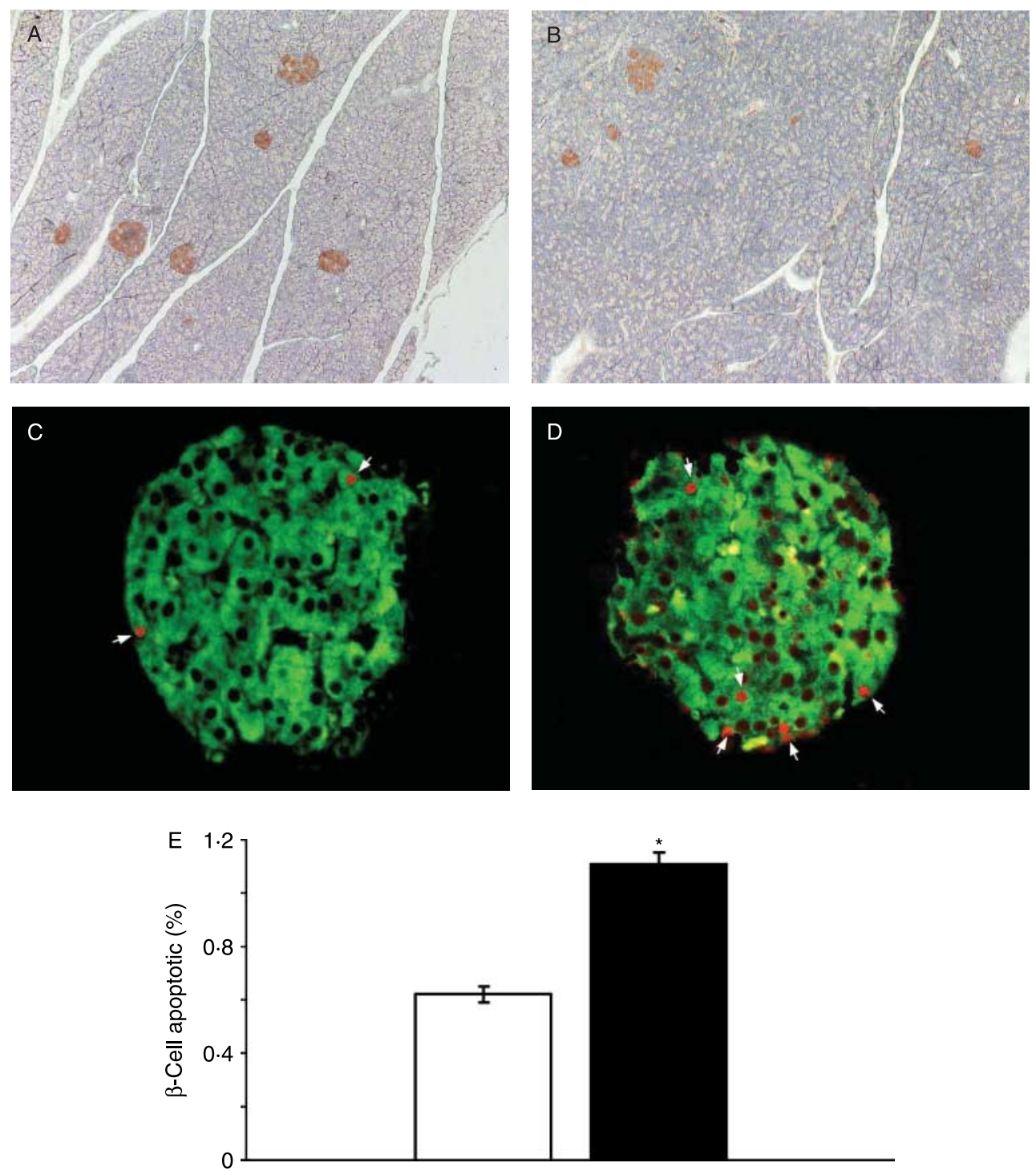

Figure 6 Pancreas sections from $C$ and FRD rats stained with insulin antibody (A and B respectively). The pancreas from $\mathrm{C}$ animals shows more islets per area than FRD $(10 \times)$ ). Apoptosis (red nuclei, arrows) observed in islets from $C(C)$ and FRD $(D)$ rats treated with propidium iodide $(20 \times)$. (E) Percentage of apoptotic $\beta$-cells in $\mathrm{C}$ (white) and in FRD (black) rats (means \pm S.E.M.); $* P<0 \cdot 05$. The results represent three different levels of the block from three animals of each group.

Despite the marked decrease in $\beta$-cell mass, FRD rats had normal blood glucose together with high-circulating levels of insulin, as well as higher in vitro release of insulin in response to glucose. These data indicate that the remaining $\beta$-cells were still sufficient to cope with the increased demand of insulin present in these rats. The fact that these animals had significantly higher glucose concentrations than control rats after an i.p. glucose load would suggest that total compensation would only be fully effective when the decrease in $\beta$-cell mass is lower than that found in our model (33\%). This assumption would be supported by the results obtained using partial pancreatectomy, in which the degree of alteration of glucose homeostasis is proportional to the percentage of the pancreas removed (Jonas et al. 1999).

The increased release of insulin measured both in vivo and in vitro in FRD rats was accompanied by a significant concomitant increase in islet glucose metabolism, GK activity and GK protein expression. GK activity is controlled by mechanisms acting at different levels, namely, protein levels (Liang et al. 1992) and subcellular compartmentalization with translocation between the cytoplasm and $\beta$-cell organelles (Tiedge et al. 1999, Stubbs et al. 2000, Rizzo et al. 2002). We found an increase in total GK protein expression (western blot and $\left.V_{\max }\right)$ and in GK activity/protein measured in the 
cytosolic fraction, which represents its highly active form (Tiedge et al. 1999). These data suggest that GK compartmentalization (shuttled from organelles to the cytosol) could be the immediate and rapid islet adaptation mechanism to cope with the increased demand of insulin occurring in FRD rats.

The changes in GK currently recorded resemble those observed in comparable but not identical conditions, namely, a) increased GK activity measured in spontaneously hypertensive rats with IR and normal glucose tolerance, without changes in its protein level (Chen et al. 1994b); b) increased GK activity reported in short-term hyperinsulinemic/markedly hyperglycemic rats (Chen et al. 1994a); c) increased GK activity in rats infused with $20 \%$ glucose, without changes in its protein level (Chen et al. 1994a), and d) high GK activity measured in islets cultured with high glucose concentrations (Liang et al. 1992). In our experimental model, no difference in blood glucose concentrations was recorded between $\mathrm{C}$ and FRD rats; however, since the latter presented impaired i.v. glucose tolerance, they would have mildly higher postprandial blood glucose levels. Consequently, our data show for the first time that in intact animals with IGT, the relative low but permanent increase in postprandial blood glucose levels is sufficient to trigger the increase of both GK activity and protein level, without affecting its mRNA levels. This latter effect was not completely unexpected, since increased GK protein expression without a concomitant increase in its mRNA has been reported by several authors (Iynedjian et al. 1989, MacDonald 1990, Liang et al. 1992). Based on reported evidence and our own data, we could assume that the increased protein mass of the enzyme could be ascribed to changes at posttranscriptional level in response to the fructose overload.

Despite the large and significant number of changes observed in GK, no significant change was measured in HK activity, mRNA levels and protein expression in the islets of FRD animals when compared with $\mathrm{C}$ islets.

Regarding the mechanism accounting for the changes observed in FRD rats, we hypothesize the following temporal sequence of events: a) there is an increase in triglyceride, saturated free fatty acids, and postprandial glucose concentrations that induce a concomitant increase in gluco-oxidative stress and IR (Peyron-Caso et al. 2002, Poitout \& Robertson 2002, Lombardo \& Hein 2007); b) these changes promote an uncompensated increase in $\beta$-cell apoptosis, with the consequent decrease in their mass; $c$ ) the small but sustained increase in postprandial blood glucose would be sufficient to trigger an increase in both GK activity and protein level in the islets, with the consequent increase in islet glucose metabolism and glucose-induced insulin secretion both in vivo and in vitro. These adaptive changes would be adequate enough to cope with the increased demand for insulin imposed by IR only in the case that $\beta$-cell mass does not fall below a threshold level (certainly lower than 33\%). If this adaptive mechanism fails to maintain glucose homeostasis, fasting, and postprandial hyperglycemia would appear promoting - at least in susceptible animals such as the DBA/2 mice - a decrease of both GK protein and glucoseinduced insulin secretion (Kooptiwut et al. 2005). The presence of decreased islet GK $V_{\max }$ values together with high blood glucose and normoinsulinemic levels in rats fed for 8 months with a sucrose-rich diet would support this assumption (Ferreira et al. 2007). Therefore, according to the magnitude and the time of exposure to high glucose levels, glucose can simultaneously decrease $\beta$-cell mass and sequentially increase GK activity, its protein mass, islet glucose metabolism, and insulin secretion, or just turn down all these compensatory changes, leading to diabetes development.

Since insulin secretion is a multifactorial modulated process, we cannot discard the possibility that other mechanisms could also be involved in the compensatory response observed in our animals.

There are marked differences in the pattern of $\beta$-cell changes - mass and function - observed in response to the IR state induced by our FRD and by the HFD (Terauchi et al. 2007) at 3 and 4 weeks after treatment respectively. In both studies, hyperinsulinemia was present, but HFD-treated animals had normal glucose tolerance. Additionally, while FRD animals showed increased islet GK activity, glucose utilization, and glucose-induced insulin secretion, the islets from HFD mice had no change in GK activity and decreased islet glucose oxidation and insulin release in response to glucose. Further, FRD rats displayed a decrease in their $\beta$-cell mass when compared with HFD animals, which exhibited an increase in this parameter. Consequently, hyperinsulinemia in FRD rats is due to an increase in $\beta$-cell function, while in HFD-fed animals it might be due to the increased number of lower-functioning islets (Terauchi et al. 2007). Based on all these differences, we can suggest that the changes induced by dietary-induced IR upon $\beta$-cell function and mass are strongly conditioned by the nutrient model used. A diet rich in fructose would exert a deeper and faster deleterious effect upon $\beta$-cell mass than a fat-rich diet.

In summary, our results provide the first evidence that the regulatory mechanisms of GK activity, namely, increment of its activity/protein concentration - demonstrated in animals with transient-induced hyperglycemia - in cultured islets and cell lines, also operate in vivo in a rat model with sustained induced IR and IGT but normal fasting glucose levels. These results also demonstrate that in a situation similar to the one observed in people at risk of developing type 2 diabetes; GK plays a pivotal role in the adaptive increased release of insulin in response to IR, even in the presence of a marked $\beta$-cell mass reduction. An impaired participation of GK in this process or a larger decrease in $\beta$-cell mass would result in a severe alteration of glucose homeostasis and diabetes development. The decreased transcription of GK in animals with long-term high or severe hyperglycemia (Jonas et al. 1999), the development of diabetes (Froguel et al. 1992, Kooptiwut et al. 2005) associated with GK mutations in the human pancreas, and the postulated regulatory effect of GK 
upon $\beta$-cell mass (Terauchi et al. 2007) would further support our assumption. Those results would also lend further support to the role of the network of GK-expressing cells in glucose homeostasis and the potential use of its activators for diabetes prevention and treatment (Matschinsky et al. 2006).

\section{Declaration of interest}

The authors declare that there is no conflict of interest that would prejudice the impartiality of this scientific work.

\section{Funding}

This study was supported by grants from Fondo Nacional para la Investigación Científica y Tecnológica and Consejo Nacional de Investigaciones Científicas y Técnicas.

\section{Acknowledgements}

The authors are grateful to R Rossi for advice on enzyme kinetics estimation, A Díaz for insulin assays, and A Di Maggio for careful manuscript edition.

\section{References}

Bezerra RM, Ueno M, Silva MS, Tavares DQ, Carvalho CR \& Saad MJ 2000 A high fructose diet affects the early steps of insulin action in muscle and liver of rats. Journal of Nutrition 130 1531-1535.

Bonner-Weir S \& Smith FE 1994 Islet cell growth and the growth factors involved. Trends in Endocrinology and Metabolism 5 60-64.

Bradford MM 1976 A rapid and sensitive method for the quantitation of microgram quantities of protein utilizing the principle of protein-dye binding. Analytical Biochemistry 72 248-254.

Butler AE, Janson J, Bonner-Weir S, Ritzel R, Rizza RA \& Butler PC 2003 Beta-cell deficit and increased beta-cell apoptosis in humans with type 2 diabetes. Diabetes 52 102-110.

Catena C, Giacchetti G, Novello M, Colussi G, Cavarape A \& Sechi LA 2003 Cellular mechanisms of insulin resistance in rats with fructose-induced hypertension. American Journal of Hypertension 16 973-978.

Chen C, Thorens B, Bonner-Weir S, Weir GC \& Leahy JL 1993 Recovery of glucose induced insulin secretion in $90 \%$ pancreatectomized rats. Diabetologia 36 1238-1244.

Chen C, Bumbalo L \& Leahy JL 1994a Increased catalytic activity of glucokinase in isolated islets from hyperinsulinemic rats. Diabetes 43 684-689.

Chen Ch, Hosokawa H, Bumbalo LM \& Leahy JL 1994b Mechanism of compensatory hyperinsulinemia in normoglycemic insulin-resistant spontaneous hypertensive rats. Journal of Clinical Investigation 94 399-404.

Chomczynski P \& Sacchi N 1987 Single-step method of RNA isolation by acid guanidinium thiocyanate-phenol-chloroform extraction. Analytical Biochemistry 162 156-159.

Delbosc S, Paizanis E, Magous R, Araiz C, Dimo T, Cristol JP, Cros G \& Azay J 2005 Involvement of oxidative stress and NADPH oxidase activation in the development of cardiovascular complications in a model of insulin resistance, the fructose-fed rat. Atherosclerosis 179 43-49.

Ferreira MR, Lombardo YB \& Chicco AG 2007 Actividades glucoquinasa y hexoquinasa en islotes de Langerhans de ratas alimentadas cronicamente con dieta rica en sacarosa. Medicina 67 121-122 (Abstract).

Froguel P, Vaxillaire M, Sun F, Velho G, Zouali H, Butel MO, Lesage S, Vionnet N, Clement K, Fougerousse F et al. 1992 Close linkage of glucokinase locus on chromosome $7 \mathrm{p}$ to early-onset non-insulindependent diabetes mellitus. Nature 356 162-164.
Gagliardino JJ, Nierle C \& Pfeiffer EF 1974 The effect of serotonin on in vitro insulin secretion and biosynthesis in mice. Diabetologia 10 411-414.

Giroix MH, Sener A, Pipeleers DG \& Malaisse WJ 1984 Hexose metabolism in pancreatic islets. Inhibition of hexokinase. Biochemical Journal 223 447-453.

Herbert V, Lau KS, Gottlieb CW \& Bleicher SJ 1965 Coated charcoal immunoassay of insulin. Journal of Clinical Endocrinology and Metabolism 25 1375-1384.

Hsu SM, Raine L \& Fanger H 1981 Use of avidin-biotin-peroxidase complex $(\mathrm{ABC})$ in immunoperoxidase techniques: a comparison between $\mathrm{ABC}$ and unlabeled antibody (PAP) procedures. Journal of Histochemistry and Cytochemistry 29 577-580.

Iynedjian PB, Pilot PR, Nouspikel T, Milburn JL, Quaade C, Hughes S, Ucla C \& Newgard CB 1989 Differential expression and regulation of the glucokinase gene in liver and islets of Langerhans. PNAS 86 7838-7842.

Jonas JC, Sharma A, Hasenkamp W, Ilkova H, Patane G, Laybutt R, BonnerWeir S \& Weir GC 1999 Chronic hyperglycemia triggers loss of pancreatic B cell differentiation in an animal model of diabetes. Journal of Biological Chemistry 274 14112-14121.

Kahn SE, Prigeon RL, McCulloch DK, Boyko EJ, Bergmann RN, Schwartz MW, Neifing JL, Ward WK, Beard JC, Palmer JP et al. 1993 Quantification of the relationship between insulin sensitivity and G-cell function in human subjects: evidence for a hyperbolic function. Diabetes 42 1663-1672.

Kharroubi I, Ladriere L, Cardozo AK, Dogusan Z, Cnop M \& Eizirik DL 2004 Free fatty acids and cytokines induce pancreatic beta-cell apoptosis by different mechanisms: role of nuclear factor-kappa B and endoplasmic reticulum stress. Endocrinology 145 5087-5096.

Klöppel G, Löhr M, Habich K, Oberholzer M \& Heitz PU 1985 Islet pathology and the pathogenesis of type 1 and type 2 diabetes mellitus. Survey and Synthesis of Pathology Research 4 110-125.

Kooptiwut S, Kebede M, Zraika S, Visinoni S, Aston-Mourney K, Favaloro J, Tikellis C, Thomas MC, Forbes JM, Cooper ME et al. 2005 High glucoseinduced impairment in insulin secretion is associated with reduction in islet glucokinase in a mouse model of susceptibility to islet dysfunction. Journal of Molecular Endocrinology 35 39-48.

Lacy PE \& Kostianovsky M 1967 Method for the isolation of intact islets of Langerhans from the rat pancreas. Diabetes 16 35-39.

Liang Y, Najafi H, Smith RM, Zimmerman EC, Magnuson MA, Tal M \& Matchinsky F 1992 Concordant glucose induction of glucokinase, glucose usage, and glucose-stimulated insulin release in pancreatic islets maintained in organ culture. Diabetes $\mathbf{4 1}$ 792-806.

Linde S, Hansen B \& Lernmark A 1980 Stable iodinated polypeptide hormones prepared by polyacrylamide gel electrophoresis. Analytical Biochemistry 107 165-176.

Lombardo YB \& Hein G 2007 Metabolic syndrome: effects of n-3PUFAs on a model of dyslipidemia, insulin resistance and adiposity. Lipids 42 427-437.

MacDonald MJ 1990 Elusive proximal signals of B-cells for insulin secretion. Diabetes 39 1461-1466.

Magnuson MA \& Matschinsky FM 2004 Glucokinase as a glucose sensor: past, present, and future. In Glucokinase and Glycemic Disease: From Basics to Novel Therapeutics, pp 1-17. Eds FM Matschinsky \& MA Magnuson. Basel: Karger.

Malaisse WJ \& Sener A 1988 Hexose metabolism in pancreatic islet. Feedback control of D-glucose oxidation by functional events. Biochimica et Biophysica Acta 971 246-254.

Marynissen G, Leclercq-Meyers V, Sener A \& Malaisse WJ 1990 Perturbation of pancreatic islets function in glucose-infused rats. Metabolism 39 87-95.

Massa L, Baltrusch S, Okar DA, Lange AJ, Lenzen S \& Tiedge M 2004 Interaction of 6- phosphofructo-2-kinase/fructose-2,6-bisphosphatase (PFK-2/FBPase-2) with glucokinase activates glucose phosphorylation and glucose metabolism in insulin-producing cells. Diabetes 53 1020-1029.

Matschinsky FM \& Davis EA 1998 The distinction between 'glucose setpoint', 'glucose threshold' and 'glucose sensor' is critical for understanding the role of the pancreatic $\beta$-cell in glucose homeostasis. In Molecular and Cell Biology of Type 2 Diabetes and Its Complications, pp 14-29. Eds F Belfiore, M Lorenzi, GM Molinatti \& M Porta. Basel: Karger. 
Matschinsky FM, Magnuson MA, Zelent D, Jetton TL, Doliba N, Han Y, Taub R \& Grimsby J 2006 The network of glucokinase-expressing cells in glucose homeostasis and the potential of glucokinase activators for diabetes therapy. Diabetes 55 1-12.

Matthews DR, Hosker JP, Rudenski AS, Naylor BA, Treacher DF \& Turner RC 1985 Homeostasis model assessment: insulin resistance and beta-cell function from fasting plasma glucose and insulin concentrations in man. Diabetologia 28 412-419.

Nandhini ATA, Thirunavukkarasu V, Ravichandran MK \& Anuradha CV 2005 Effect of taurine on biomarkers of oxidative stress in tissues of fructosefed insulin-resistant rats. Singapore Medical Journal 46 82-87.

Ogilvie PF 1933 The islands of Langerhans in 19 cases of obesity. Journal of Pathology and Bacteriology 37 473-481.

Peyron-Caso E, Taverna M, Guerre-Millo M, Véronèse A, Pacher N, Slama G \& Rizkalla SW 2002 Dietary (n-3) polyunsaturated fatty acids up-regulate plasma leptin in insulin-resistant rats. Journal of Nutrition 132 2235-2240.

Poitout V \& Robertson RP 2002 Minireview: secondary cell failure in type 2 diabetes a convergence of glucotoxicity and lipotoxicity. Endocrinology 143 339-342.

Porte D Jr 1991 B-Cells in type II diabetes mellitus. Diabetes 40 166-180.

Randle PJ 1964 The interrelationships of hormones, fatty acid and glucose in the provision of energy. Postgraduate Medical Journal 40 457-463.

Rebolledo OR, Marra CA, Raschia A, Rodriguez S \& Gagliardino JJ 2008 Abdominal adipose tissue: early metabolic dysfunction associated to insulin resistance and oxidative stress induced by an unbalanced diet. Hormone and Metabolic Research 40 794-800 (Epub ahead of print).

Rizzo MA, Magnuson MA, Drains PF \& Piston DW 2002 A functional link between glucokinase binding to insulin granules and conformational alterations in response to glucose and insulin. Journal of Biological Chemistry 277 34168-34175.

Robertson R, Zhou H, Zhang T \& Harmon JS 2007 Chronic oxidative stress as a mechanism for glucose toxicity of the beta cell in type 2 diabetes. Cell Biochemistry and Biophysics 48 139-146.

Rutkowski DT \& Kaufman RJ 2004 A trip to the ER: coping with stress. Trends in Cell Biology 14 20-28.
Sambrook J, Fritsch EF \& Maniatis TE 1989 Molecular Cloning: A Laboratory Manual. edn 2, Cold Spring Harbor, NY: Cold Spring Harbor Laboratory. Scaglia L, Cahill CJ, Finegood DT \& Bonner-Weir S 1997 Apoptosis participates in the remodelling of the endocrine pancreas in the neonatal rat. Endocrinology 138 1736-1741.

Schuit F, Moens K, Heimberg H \& Pipeleers D 1999 Cellular origin of hexokinase in pancreatic islets. Journal of Biological Chemistry 274 32803-32809.

Shulman GI 2000 Cellular mechanisms of insulin resistance. Journal of Clinical Investigation 106 171-176.

Stubbs M, Aiston S \& Agius L 2000 Subcellular localization, mobility, and kinetic activity of glucokinase in glucose-responsive insulin-secreting cells. Diabetes $492048-2055$.

Terauchi Y, Takamoto I, Kubota N, Matsui J, Suzuki R, Komeda K, Hara A, Toyoda Y, Miwa I, Aizawa S et al. 2007 Glucokinase and IRS-2 are required for compensatory $\beta$ cell hyperplasia in response to high-fat diet-induced insulin resistance. Journal of Clinical Investigation 117 246-257.

Thorburn AW, Storlien LH, Jenkins AB, Khouri S \& Kraegen EW 1989 Fructose-induced in vivo insulin resistance and elevated plasma triglyceride levels in rats. American Journal of Clinical Nutrition 49 1155-1163.

Tiedge M, Steffeck H, Elsner M \& Lenzen S 1999 Metabolic regulation, activity state, and intracellular binding of glucokinase in insulin-secreting cells. Diabetes 48 514-523.

Weyer C, Bogardus C, Mott D \& Pratley RE 1999 The natural history of insulin secretory dysfunction and insulin resistance in the pathogenesis of type 2 diabetes mellitus. Journal of Clinical Investigation $104787-794$.

Received in final form 25 November 2008

Accepted 27 November 2008

Made available online as an Accepted Preprint

27 November 2008 